\title{
The Implementation of E-Procurement Related to Government's Goods/ Services in Department of Public Works Medan
}

\author{
Asima Yanty Siahaan \\ Department of Public Administration \\ University of Sumatera Utara \\ Medan, Indonesia \\ asimayantysiahaan@gmail.com
}

\author{
Malikatul Khamdiyah \\ Department of Public Administration \\ University of Sumatera Utara \\ Medan, Indonesia \\ pemilik.malika@gmail.com
}

\begin{abstract}
In accordance with the changing times, public service reform as refflected in the procurement of goods/services of the government. The shift procurement manuall to electronic influence the implemented of e-procurement of goods/services to create good and clean governance. This change begins with the issuance of regulations that regulate under the Presidential Regulation Number 54 of 2010 which was finally amended into Presidential Regulation Number 4 Year 2015. This study used qualitative descriptive by using the policy implementation theory stated by George Edward III where the variables that determine the effectiveness of implementation are communication, resources, disposition and bureaucratic structure. The implementation of e-procurement related to government's goods and services at departement of public works Medan has been implemented well although not maximized yet. The variables that become the benchmark of this study have not been met optimally especially the limited quantity of human resources that implementers to have.
\end{abstract}

Keywords-implementation, procurement of goods/services, eprocurement

\section{INTRODUCTION}

One of the implementation of e-government in Indonesia in the form of procurement of government goods or services. Government goods or services are two basic things that are needed in the implementation of a particular activity. Initially the procurement of government goods or services used a conventional way in which the parties of users and providers of goods / services meet face-to-face. However, the method resulted in so many losses due to irregularities perpetrated by procurement actors as well as providers of goods and services.

To reduce or minimize irregularities in the procurement of goods/ services conventionally, the government has set a procurement concept of goods/ services by e-procurement as set out in Presidential Regulation No.4 Year 2015 on Procurement of Government Goods/ Services. The implementation of e-procurement is expected to apply the principle of procurement of goods/ services there are effective, efficient, transparent, open, competing, fair and accountable so as to achieve good and clean government.

As other Local Governments, Medan Government has implemented e-procurement since 2012 as evidenced by the issuance Mayor of Medan Regulation No. 38 Year 2011 on Electronic Procurement Service (LPSE) Medan. One of the SKPD that has implemented e-procurement is the Department Public Works Medan. Analisadaily (2016) explained that the Public Works Department of Medan is the SKPD most often procure goods/ services where has recorded in the second quarter in 2016, 35 packages have been completed the implementation of the auction. While 172 more packages are still in the verification file and will follow the tender process and most of the auction package that has been entered into the system is a physical project that generally belongs to the Department of Public Works.

The successful implementation of e-procurement is primarily determined by resources consisting of human resources, financial resources and supporting facility resources. But the more crucial factor is the human resources because they will implement e-procurement in accordance with applicable regulations. If the regulation is good, but the human resources are inadequate in quality and quantity then the implementation of e-procurement will not run effectively.

The readiness of Human Resources is still a constraint in the implementation of e-procurement especially related to electronic services (e-services) both in quality and quantity. Therefore, in addition to preparing infrastructure, application systems, regulatory tools, it is also necessary to prepare skilled procurement personnel with sufficient quantities that understand the e-procurement system.

Based on the above description, the authors are interested and want to discuss more deeply about "Implementation of EProcurement in Procurement of Goods / Services Government in the Department of Public Works Medan"

\section{LITERATURE REVIEW}

\section{A. E-Government}

According to (Rohman 2008) e-government is the application of information and communication technology in and with outsiders who are expected to improve the performance of government and meet the expectations of society will improve the quality of government. Meanwhile, according to (Hardiansyah 2011) e-government is a set of 
concepts for all actions in the public sector involving information and communication technology in order to optimize the efficient, transparent and effective public service process.

The development of e-government is an effort to develop electronic-based governance in order to improve the quality of public services effectively and efficiently. According to (Gunawan 2015) states that through the development of egovernment carried out structuring management systems and work processes in the government environment by optimizing the utilization of information technology. Utilization of information technology includes 2 (two) related activities of data processing, information management, management systems and work processes electronically, the utilization of information technology progress so that public services can be accessed easily and cheaply by the community in all regions of the country.

\section{B. E-Procurement}

Based on (LKPP 2010) e-procurement is a concept of procurement of goods/ services government conducted with the use of technology electronically in order to facilitate the transaction process in order to create a maximum public service. Procurement of government goods/ services electronically can be done in two ways there are e-tendering and e-purchasing. The government procurement of goods and services electronically is the Procurement of Goods, Procurement of Construction Works, Procurement of Consulting Services and Procurement of Other Services.

In the procurement of goods/ services the government should apply principles - principles in order to increase public confidence in the procurement process of goods/ services because the results can be accounted to the community in terms of administration, technical and financial. The principles of procurement of goods/ services according to Presidential Regulation No. 4 Year 2015 concerning Procurement of Government Goods/ Services are efficient, effective, transparent, open, competitive, fair/ non discriminatory and accountable.

\section{RESEARCH METHODS}

The form of research used in this research is descriptive method with qualitative approach. In this study, the approach used is qualitative by conducting in-depth interviews, observations, documentation studies and library studies by linking policy implementation variables based on George Edward III's opinion that policy implementation is determined by four variables: communication, resources, disposition and bureaucratic structure. Researchers chose the approach of the study because the research is comprehensive skin (holistic), dynamic and not generalization.

There are two types of research informants: Key informants (key informants) and main informants. The key informants in this study are the Working Group of Public Works Department of Medan City which amounted to two (2) persons. While the main informants in this study were employees of Procurement Services Medan which amounted to five (5) persons and Electronic Procurement Services
Officers (LPSE) Medan City which amounted to five (5) people.

Data collection techniques in this study using primary data collection techniques are conducted directly on the location of research through interviews and observation. Technique of collecting secondary data through literature study and documentation study to support primary data. The activity of data analysis through data reduction, data presentation and decision making or conclusion.

\section{FINDINGS AND DISCUSSIONS}

\section{A. Implementation of E-Procurement in Procurement of Government Goods/ Services in the Public Works Department}

\section{1) Communication}

Communication is the process of delivering information between the communicator to the communicant, this can happen vertically or horizontally. This communication can be seen through the process of delivering information between implementors related to different agencies, the delivery of information between the parties involved in an institution and the intensity of communication made.

Department of Public Works Medan has made good communication to the implementor in implementing eprocurement process evidenced by regular meetings once a week and discussions are always done every day. For the first time, communication is done formally through an official letter issued by the Service on the auction request. After formal communication is approved, it is followed by informal communication conducted when needed, can directly meet in the office or information can also be delivered via mobile phone. Well, such communication is only valid between the Department of Public Works and the Procurement Service and LPSE vice versa.

However, if the delivery of information to the service providers is only done through the website LPSE. Any delivery of information and interactions that occur in the implementation process of e-procurement, especially auctions, is only done through the internet. This is implemented in accordance with the regulations governing e-procurement to avoid deviations that occur when manually or face-to-face.

Not only about the process of information delivery, in this study communication is also assessed by the intensity of communication made between the parties concerned. The intensity of communication between the parties is done in accordance with the necessary requirements and in accordance with a predetermined planned schedule.

Unlike other agencies, LPSE always standby to every implementor, if need help or explanation about e-procurement so it is not surprising if LPSE is often visited by either the eprocurement impelementor or service provider. Not only face to face directly, but also receive services and questions by phone so that the communication process that runs can not be determined its intensity because sometimes never in one day not receive guests but on the other very much receive guests. 
Overall, we can see that the communication between the implementor of e-procurement policy (the Working Group of Public Works, Procurement Service and LPSE) as the implementing party and the provider of goods/ services has been well established. This is evidenced from the process of delivering information between the related implementors (different institutions), fellow implementors in one institution and the intensity of communication between the relevant implementors described above.

\section{2) Resources}

\section{a) Human Resources (Staff)}

To facilitate our understanding of the inter-agency linkages, the following describes the linkage between the implementation of e-procurement in the procurement of government goods/ services at the Department of Public Works of Medan:

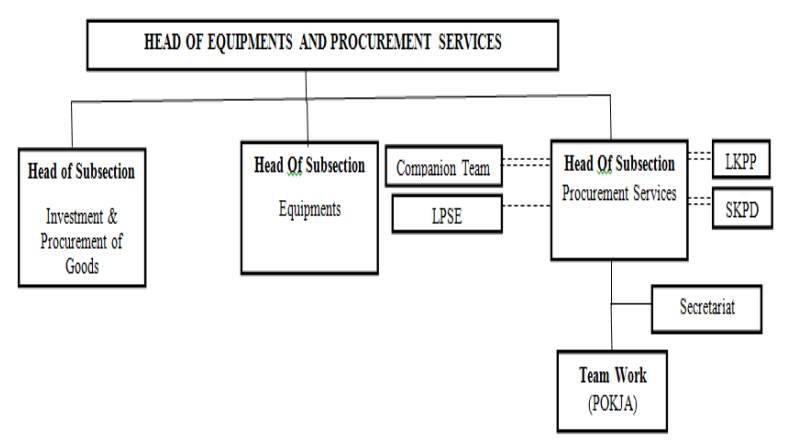

IFORLATION:

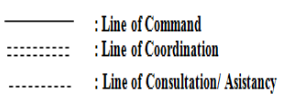

In quantity, the number of working groups coming from the Public Works Agency Medan is eight (8) persons from the total working group of 27 people and the staff at Procurement Service (LP) total of 16 people and LPSE employees amounted to 15 people who also participated in e-procurement implementation whereas at auction there are about 500 auctions each year. Based on the above and the information obtained, the number of available human resources is very less to handle such auctions.

When viewed from the quantity or amount, for the workload borne by the technical implementer in the auction electronic not appropriate from the workload. The burdens they bear are unsuitable and too much so they feel tired of continuing to work in accordance with their duties in the implementation of e-procurement.

Although the quantity is insufficient in the implementation of e-procurement in the procurement of goods/ services government in the Department of Public Works Medan, but the quality is very good because every staff or staff working in the realm of procurement of goods/ services the government must have a certificate procurement of goods/ services government through exams organized by LKPP. Based on the analysis of the exposure, it is known that human resources which is the implementation of e-procurement in the procurement of goods/ services government in the Department of Public Works Medan is quite good seen from the quality even in the case of inadequate quantity

\section{b) Financial Resources}

Financial resources is the capital adequacy in a program or policy that will support all activities and facilities needed for the implementation of the policy. Financial resources are also something that is needed in the procurement of goods/ services, if not available enough then the implementation of procurement will not run smoothly.

Until now, the financial resources in the implementation of e-procurement in the procurement of good/ services in the Departement of Public Works Medan already supports, it can meet implementation of e-procurement well because $100 \%$ of funding sources come from APBD that has been budgeted each year .

\section{c) Support Facilities Resources}

Supporting facilities are physical and non physical facilities (applications) or facilities and infrastructure that support the implementation of e-procurement in the procurement of goods/ services government in the Department of Public Works Medan.

The Office of Procurement Services has sufficient supporting facilities where there is a substantial need required in the implementation of e-procurement. Each employee and member of the working group (Pokja) gets each one unit of commission to carry out its duties which have been equipped with internet network to be able to access and perform its duties in electronic auctions. However, in reality the Room Service Procurement is quite narrow and inadequate so that between the desk employees with each other is suffocating enough to cause less comfortable among the employees.

Unlike the facilities owned by the Office of Procurement Services, the Office of Electronic Procurement Service (LPSE) has adequate facilities in terms of space owned. The rooms that are owned are living room or lobby, bidding room, server room for administrator and room verifier.

Based on the above description proved that the supporting facilities owned by the implementor e-procurement agency is quite adequate physically and system. In LPSE Medan itself, already has a special room that is needed and is equipped with a computer so that the staff can work with the maximum. Although physically adequate, still need additional facilities that is in the form of application upgrades / upgrades to facilitate the implementation and reduce technical errors.

\section{3) Disposition}

The disposition of the implementor is the tendency of attitudes and understanding of the implementor that will affect the achievement of the objectives of the policy implementation. Each implementor can have different attitudes or understandings so that the policy does not run in accordance with the intended purpose.

The e-procurement policy established by the government is responded positively by the implementors of Department Public Works Medan. The implementors support the stipulation of this policy and assess that e-procurement is a 
good solution because of the modern times that need to be utilized technology that has been developed at this time, in addition e-procurement is considered better than the procurement manually because viewed from the economic policy this is more cost-effective (no need to use paper), saves time due to the calendar time schedule (no holiday deduction) and reduces the fraud that ever happened when using procurement manually. In harmony with that, all employees showed a positive attitude in implementing e-procurement also viewed from the performance that has been implemented, the employees perform their duties very well.

Regardless of the above, until now the implementors have done their job well and understand the basis of e-procurement policy and know clearly about the history of the procurement of goods/ services government manually into e-procurement. The rationale for such changes is due to technological developments and globalization that require policies to run effectively and efficiently, in addition to avoiding identical fraud occurring as a result of meetings between service providers and working groups (Pokja).

The principles of procurement of goods and services that is efficient, efective, transparent, open, compete, fair and accountable almost fully achieved that is supported by the professionalism of the implementors and their compliance with existing regulations and SOP as evidenced by its good performance. In addition, the implementation of the implementor is very good on this policy because every implementor who wrestle in the realm of procurement of goods/ services the government has a certificate of graduation exam on the procurement of goods/ services organized by LKPP.

\section{4) Bureaucratic Structure}

Department of Public Works can not do e-procurement alone, need to coordinate with Procurement Service and Electronic Procurement Service of Medan. So, we know that the bureaucratic structure has a very important role to achieve the implementation of a policy.

As for the benchmarks of the bureaucratic structure is the Standard Operational Procedure (SOP) owned by related agencies and the deployment of the duties of each employee. SOP is very determine the performance of employees because in it work reference applicable in the implementation of eprocurement, in addition to the views of SOP also need to see the flow of delivery from the central government to the region. While the deployment of the duties of each employee can be seen from the main task and function and the span of control between the leadership and employees.

The flow of the latest regulatory submission or SOP from the central government is only done through the internet which can be known through the LKPP portal in the latest regulatory column. However, if there is a very urgent regulation such as Presidential Instruction will be submitted through a circular letter. The latest e-procurement-related regulatory submission that rely solely on the internet requires executors to take an active role in finding the latest information.

In addition to the SOP, the bureaucratic structure is also seen through the deployment of tasks and the span of control between the leadership and employees. In the implementation of e-procurement at the Department of Public Works Medan, the Procurement Services which includes the Working Group (Pokja) has the role of e-procurement technical implementor. The total of all technical implementors in the implementation of the Department of Public Works Medan amounted to 41 people (Total between working works and Procurement Services Officers). They work in accordance with the Order of Duty (SPT) issued, each team amounting to three (3) or five (5) people in accordance with the specified regulations that each technical implementer amounted to a gas.

\section{B. Challenges and obstacle}

\section{1) Individual}

The individual challenges or constraints on the implementation of e-procurement are every implementor is demanded more quickly, accurately, professionally and every day demanded to work even though the work time is over, due to quantity. Inadequate human resources then the files that must be checked enough so that the implementor is required continue to work. In addition, the implementor should always be active and up to date with the latest regulatory developments in order not to be difficult in work due to regulations that are often updated.

\section{2) Technical}

Technical barriers or challenges are those that occur due to technical errors that are out of the estimates of the implementor. The obstacles and challenges are due to technical problems, such as electricity that suddenly extinguished resulting in the speed of connection or internet network decline and eventually could lead to the server suddenly down.

\section{3) Resources}

The first challenges and obstacles are the inadequate support facilities resources where the computer version is not up-to-date and the application version of SPSE has not been upgraded. Then, on the inadequate human resources in quantity. This is hampering because so many auction packages have to be done every year, but the human resources involved in them are very few and limited.

\section{4) Communication}

Communication is one of the most important roles in the implementation of policy. Ineffective communication is also an inhibiting factor, while non-current communication usually occurs between the Working Group (Pokja) as the technical implementer with SKPD related to the auction implementation. Often the Working Group (Pokja) has reminded SKPD to carry out its initial duties in applying for the auction, but SKPD is so long in carrying out its duties that it hinders the auction process for the future.

\section{5) Complaint}

A complaint occurs if the provider of goods/ services losing the tender process does not receive the results decided by the Working Group so that the provider / goods report to APIP. The challenge is when there is a rebuttal from the suppliers who lose in the tender process, where the Working Group (Pokja) is accused of conspiring with the winning 
provider so that there are threats to the implementor. Barriers must be passed by the implementor is when received a call from the Government Internal Supervisory Apparatus (APIP) on complaints from providers who lost in the auction so that the implementation time of the implementor is reduced. In addition to being harmed in time, often the implementer is also mentally or mind impaired.

\section{Conclusions And ReCOMmendations}

\section{A. Conclusion}

\section{1) Communication}

Communication that occurs between the employees of one agency and fellow implementors between agencies running quite well where communication is initiated in the form of formal and then followed by non-formal communication and is direct. While the communication that exists between the implementor with the provider is only implemented through the internet in the form of announcements and proceed to the document explanation process. The communication process that runs until now has run quite well and smoothly.

\section{2) Resources}

These indicators include human resources, financial resources and support facility resources. Variable human resources have adequate quality, but the quantity of human resources needed is still inadequate. On financial resources, is sufficient because the planning has been done and determined in the APBD. In harmony with that, the resources of supporting facilities are also sufficient to be seen from the available physical facilities.

\section{3) Disposition}

These indicators include the attitudes of the implementor and the implementationor's understanding of the policies being implemented. The attitude of the implementor in implementing this policy is very supportive and obedient to the regulations that become the reference and understanding owned by the implementors of both history and regulation are good enough.

\section{4) Bureaucratic Structure}

This indicator includes SOP and the deployment of tasks performed by the implementors. Every intansi associated with the implementation of e-procurement already has SOP as its reference, even in LPSE there is a very detailed SOP from various tupoksi division owned by the institution. In addition, the distribution of duties and control ranges contained in the Public Works Department, Procurement Services and Electronic Procurement Services are appropriate.

\section{B. Suggestion}

1) Due to poor communication between Procurement Service and SKPD, all e-procurement implementers in the procurement of goods / services of government in the Public Works Agency are advised to communicate in accordance with the procedure and run the SOP fully in carrying out its responsibilities and provide the best performance for e procurement can be implemented maximally.

2) Due to the narrow and poor room, all Office eprocurement implementers in the procurement of goods / services in the Public Works Department is recommended to complete the physical facilities by adding space and expanding the existing room so as to support the implementation of the implementation of the processor to work properly, comfortable and smooth.

3) Due to the inadequate quantity of Working Group of Medan City Government, it is suggested to be able to add to the e-procurement working group that is required for the completion of the task to run maximally with the appropriate workload.

\section{References}

[1] Analysis, 35 Package of Project Completed Tender, Retrieved on 7 January 2017 At 20.43 from http://harian.analisadaily.com/ kota/news/35-package-project-2016-signed tender/241876/2016/ 06/06.

[2] Anderson, James E., 2006, Public Policy making-Sixth Edition, Houghton Mifflin Company, Boston.

[3] Dunlevy, Patrick, Helen Margetss, Simon Bastow and Jane Tinkler, 2006, Digital Era Governance: IT Corporation, the state and EGovernment, Oxford University Press, New York.

[4] Gunawan, Cakti Indra, 2015, Management Information System and EGovernment, CV. IRDH, Purwokerto.

[5] Hardiansyah, 2011, Quality of Public Service: Concepts, Dimensions, Indicators and Implementation, Publisher Gava Media, Yogyakarta.

[6] LKPP, 2010, Module on the Use of E-Procurement: Training of Procurement of Goods / Services Provincial Government / First, Jakarta.

[7] Rohman, Ahmad Ainur, M Masud Said, Saiful Arif, Purnomo, 2008, Public Service Reform, PlaCids Averroes, KID \& Averroes Press, Malang.

[8] Singarimbun, Masri \& Sofian Effendi, 2012, Survey Research Methods, LP3ES, Jakarta Subarsono, A.G., 2006, Public Policy Analysis, Concepts, Theory and Applications, Pusataka Pelajar, Yogyakarta.

[9] Tangkilisan, Hessel Nogi., 2003, Ground Public Policy, Lukman Offset, Yogyakarta.

[10] Widodo, Jokowi, 2015, Presidential Regulation No. 4 of 2015, On Procurement of Goods / Services Government, Jakarta.

[11] Yudhoyono, Susilo Bambang, 2010, Presidential Regulation No. $54 / 2010$ concerning Procurement of Government Goods / Services, Jakarta. 